\title{
The Administrative System Reform and Practice towards Service-oriented Government
}

\author{
-Taking Shunde District Guangdong Province as an Example
}

\author{
Li Chongzhao \\ Yunnan University of Finance and Economics \\ School of Finance and Public Management \\ Kunming, Yunnan,P.R.China 650221 \\ 77812032@qq.com
}

\begin{abstract}
As the deepening of the socialist market economy reform in China, continuing to deepen institutional and administrative system reforms and accelerate the transformation of government functions has become an important part of the reform. This study takes the Shunde District of Foshan City, Guangdong Province as an example, it analyzes the existing research and policy texts to analyze the practices, effectiveness, and problems of the administrative system reform since 2009 in Shunde District, and summarizes the experience and inspiration of the administrative system reform in Shunde District.
\end{abstract}

Keywords-Administrative system, Reform, Service-oriented government

With the deepening of the reform of China's socialist market economy system, the government's functions will also change. The 2017 Party Congress's report on the Nineteenth Congress clearly put forward: "Deepen institutional and administrative system reforms, and make overall arrangements for various types of institutions, scientifically allocate party and government departments, and establish institutional powers and clear responsibilities." ${ }^{[1]}$ At the Third Plenary Session of the 19th Party Congress in 2018, it was proposed that the transformation of government functions and the optimization of government agency setup and function allocation are important tasks for deepening the reform of the party and state institutions. ${ }^{2]}$

The exploration and implementation of the reform of the administrative system requires the unified deployment of the top management of the central government and the active participation of local governments in innovation. The Chinese government has often adopted a "pilot" approach in the process of promoting the transition of the administrative

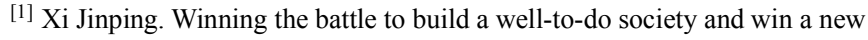
era of great socialism with Chinese characteristics. People's Publishing House, 2017 Edition.

[2] Compendium of the Third Plenary Session of the 19th Central Committee of the Communist Party of China. People's Publishing House, 2018 Edition.
}

system, that is, allowing local governments to explore ways to solve problems according to the actual situation. Successful local experiences will be absorbed into the policy after being recognized by the central government, and then pushed in and widened nationally. ${ }^{[3]}$ As the frontier of reform and opening up, Guangdong Province has always assumed the important task of reforming and reforming the country's administrative system. In March 2009, the Guangdong Provincial Committee and the Provincial Government issued the Opinions on the Institutional Reform of the People's Governments of Cities and Counties of Guangdong Province and the Opinions on Deepening the Reform of the Administrative System before the Reform of the Administrative System in Shenzhen. It clarifies the guiding ideology, reform principles, main tasks, and pilot requirements of the institutional reforms of the people's governments of cities and counties.Under the policy guidance and deployment of the Party Central Committee, the State Council and the Guangdong Provincial Party Committee and Provincial Government, Shunde District has once again become the "scientific development, first trial" area in Guangdong Province, which has initiated a new round of all-round reforms in the administrative management system.

This paper sorts out the main practices and innovations, effectiveness and impacts as well as existing problems in advancing administrative system reforms in Shunde District of Foshan City, Guangdong Province since 2009. Starting from the practice of the district (county) level administrative system reform pilot, it sums up the government's experience and inspiration to promote the transformation of government functions and public service innovation.

\section{THE MAIN PRACTICES AND INNOVATIONS OF}

\section{ADMINISTRATIVE SYSTEM REFORM IN SHUNDE DISTRICT}

\section{A. Implementing "majority" system reform}

First of all, optimize the merger of party and government

\footnotetext{
${ }^{[3]}$ Han Botian. Formulating Policies through Experiments: China's Unique Experience. Contemporary Chinese History Study, May 2010.
} 
agencies. In accordance with the functional orientation of economic regulation,market supervision, social management, and public services, Shunde District, in addition to the National People's Congress, the CPPCC outside the party, government, engineering, group full system and nine departments are included in the scope of institutional integration, these nine ministries are Foshan City vertical management of industry and commerce, land tax, quality supervision, drug supervision, public security, land, planning, social security, and weather bureau. The original 41 institutions have been organically integrated into 16 , of which the number of government departments has been reduced from 29 to 10 . The number of Party committees in the district was reduced from 12 to $6 .{ }^{[4]}$ In October 2014, Guangdong Province issued the Notice of the Functional Transformation and Institutional Reform Plan of the People's Government of Shunde District, and Shunde District carried out new organizational adjustments based on the last round of the reform of the major departments. The newly established District Civil Affairs and Human Resources Social Security Bureau, the former District Administrative Supervision and Audit Bureau, the District Sports and Tourism Bureau, the District Civil Affairs Religion and Foreign Affairs and Overseas Chinese Affairs Bureau, the District Human Resources and Social Security Bureau are no longer retained, the District Food and Drug Administration has added a brand to the District Market Supervision Administration.

Second, improve the operating mechanism of the party and government.Improve decision-making error correction mechanism and accountability system. We will establish an administrative accountability system that focuses on the heads of major departments and improve the performance evaluation system for departments and civil servants. Strengthen the construction of a procedural system for the supervision of administrative power, explore the establishment of effective methods of supervision outside the system, make full use of the power of the media, networks and social organizations, autonomous organizations, and comprehensively supervise administrative operations. Strengthen the construction of democratic politics, establish a district and party decision-making mechanism, and support the "two representatives and one committee" to perform the functions of participating in political affairs and democratic supervision.

\section{B. Carry out "simplify politics, strengthen town" power}

\section{reform}

Shunde, as one of the pilot units of the Guangdong Province to deepen the reform of the administrative management system and to "simplify politics and strengthen the town," has focused on the goal of building a service-oriented government.It began to promote the "double transfer" of government functions. Shunde District administers Ronggui Street as a pilot project, vigorously promotes the "simplification of politics, and strengthens the town" reform, and provides demonstrations for deepening county-level and town-level administrative reforms in Guangdong Province.

\footnotetext{
${ }^{[4]}$ Guangdong Office of Institutional Drafting Committee. Reform of party and government structure in Shunde District of Foshan City. Reform of Guangdong Province's Large Department System-Exploration and Practice. 2011 Edition
}

The first is to implement the government's functions from the "up" to the "down" decentralization. In August 2009, according to the "Certification of Guangdong Provincial Party Committee and Guangdong Provincial People's Government on Comprehensive Reform Testing in Shunde District of Foshan City.On the basis of maintaining the original system, the government will decentralize administrative examination and approval matters to the town (street). In accordance with the principle of "macro decision-making authority shifts upwards, and micro-management rights move downwards," the trial reform of the reform of powers and interests is fully promoted. The management, approval and service matters directly related to the public are, in principle, handed over to the town (street) government for completion.Second, the implementation of horizontal government functions from the "inside" to "outside" simple governance. In accordance with the principle of "decentralization of rights and reduction of government administration", the government should increase its stance to the market, society, and self-government at the grassroots level, promote social management and public service system reform, and build a diversified social governance system.

\section{THE MAIN ACHIEVEMENTS AND INFLUENCES OF THE}

\section{ADMINISTRATIVE SYSTEM REFORM IN SHUNDE DISTRICT}

Shunde District takes the transformation of government functions as the core and the establishment of service-oriented government as its goal, and promotes the administrative system in an all-round way. It has been fully affirmed by the Central Government and highly appraised by the social masses. The reform has had remarkable results and influence.

\section{A. Straighten out the relationship between power and} responsibility and promote the transformation of government functions

Shunde District has created a precedent for the reform of China's county-wide ministry system. While reforms have improved the level of government services, they have also promoted the transition from government functions to service-oriented ones. The highlight of the reform of the large-scale system in Shunde District is the overall planning of party committees and government agencies. It merges the functions of the party and government agencies that are the same or similar. It adopts a joint office approach to break the traditional institutional separation of the party and the government, and establishes an organizational structure that combines party and government.

\section{B. Straighten out government-level relations and improve administrative efficiency}

The reform establishes a new model of party-government linkage.The government level has been compressed, the decision-making and execution system has been innovated, the management chain has been shortened, and the administrative level has been reduced. Through the decentralization of powers on a layer by layer basis, the administrative procedures in the district have been greatly reduced.. 


\section{Straighten out the power structure to achieve "broadness}

\section{but not balance, balance and balance"}

The decision-making mechanism is innovative and the power of macro decision-making is shifted upwards. To a certain extent, the problems caused by decision-making and implementation in some departments have been changed, and the democratization and scientization of decision-making have been promoted. The District Discipline Inspection Commission dispatches disciplinary inspection teams to government departments to implement independent, full-process supervision over the decision-making and implementation process of each department, and to achieve the flattening of powers, positions, and responsibilities, as well as decision-making and implementation.

\section{Straighten out the relationship between the government and society, and explore multiple governance models}

The Shunde district government actively abandons the concept of an all-round government that "does everything, manages everything," and gradually devolves the "right" to the grassroots or to the society.

\section{PROBLEMS IN THE REFORM OF ADMINISTRATIVE}

\section{SYSTEM IN SHUNDE DISTRICT}

\section{A. Administration and finance have not completely straightened out provincial work}

As the reform of the large-scale system in Shunde District is reform at the county level, the provincial level has not implemented a large-scale system.In the vertical direction, there is a problem of the subordinate department to multiple superior departments. For example, the Bureau of Market Safety Supervision has its rank at the branch level, and the Bureau of Industry and Commerce and the Bureau of Quality and Technical Supervision, which were incorporated into the Bureau as a whole, are the deputy department level. The district financial work has not completely connected with the province, which has affected the normal development of related work to some extent.

\section{$B$. The current personnel management system affects the}

\section{effectiveness of the reform of the major departments}

After Shunde changed from vertical management to territorial management and integrated settings, departmental staffing and departmental functions did not adapt. As the power to formulate local wages is limited, most of the departments and agencies work together and people from different levels and different departments reorganize.

\section{Horizontal coordination between departments needs to be strengthened}

Compared with the reform, the coordination affairs have been greatly reduced, but the working mechanism is still insufficient. After being appointed as the head of the department, the Standing Committee of the District Committee was strengthened in the resolution of departmental affairs. However, when it comes to the business of other departments, it is necessary to increase the level of coordination.

\section{THE EXPERIENCE AND ENLIGHTENMENT OF THE}

\section{REFORM OF ADMINISTRATIVE SYSTEM IN SHUNDE District}

The reform is not merely an institutional reform, but also an institutional innovation that is of political reform significance. It provides useful ideas for the promotion of administrative system reforms by local governments at all levels.

\section{A. The support of the provincial government is crucial to the continuous progress of the reform}

The encouragement and protection of the Guangdong Provincial Party Committee and the provincial government for the reform of the large-scale system in Shunde District was the key to the fact that the reform has not been "polished" due to "people going". The Guangdong Province issued a series of opinions and proposals to promote the reform of the administrative system, which provided a strong policy guarantee for the smooth implementation of the reform of the government agencies in Shunde District. It also lays a foundation for the reform to break the traditional relationship between the bar and the establishment of a large-scale system with unified organic functions.

\section{B. Fully taking into account the interests of all parties and forming a multi-layered reform joint force}

Shunde reform conforms to the objective needs of the continuous improvement of the socialist market economy, satisfies the masses' demands for the transformation of government functions and the improvement of administrative efficiency, and has won the greatest legitimacy and the broadest mass base for reforms. Shunde District jumped out the thinking mode of streamlining institutions and diversionaries, formulated a comprehensive plan for cadre arrangements. It maintained the ideological stability of the cadre team, minimized the resistance to reform, and achieved a smoother transition and transition.

\section{Rationally design reform plans to ensure steady progress of reforms}

The reform in Shunde District conforms to the trend of China's administrative reform. Prior to the introduction of the reform plan for the major departments, the main planners for the reform of Shunde were extensively investigated throughout the country. After fully drawing on and drawing on the useful experience of the establishment and operation of government agencies in Hong Kong, Macao, and Singapore, we closely planned the actual conditions in Shunde District. In particular, thorough consideration of the problems that may be encountered led to the formation of a well-planned reform of government agencies. At the same time, the reform in Shunde District adheres to the principles of "allowing reforms to fail, not allowing non-reform" and "do not argue, permitting trials, and correcting promptly" to ensure that reforms can be boldly advanced and adjusted in time to achieve steady progress in reforms.

\section{People-oriented, formulate and improve a comprehensive cadre service plan}

The "top leaders" of the 16 institutions in the reform of the big department in Shunde District has not been selected from the leaders of the 41 institutions. Instead, they take the 
deputy positions of the district committee and the district government and the newly established district council members to serve as two methods. Among them, deputy secretaries, deputy district heads, and standing committee members occupy 11 of these posts, and newly established district committee members serve as the remaining five positions. The original director retired as the deputy director, and the deputy director retired from the office as a member of the bureau, maintaining the original administrative level and establishment. The division of labor among the posts is clear. The overlapping of powers and responsibilities does not overlap. It minimizes the resistance to reform and ensures the ideological stability of the cadres.

\section{CONCLUSION}

After 2014, the pace of administrative system reform in Shunde District has slowed down. Currently, re-simplifying the problems, experiences, and inspirations of the Shunde reform will provide useful references and lessons for the party and the government to further deepen institutional and administrative system reforms.

\section{REFERENCES}

[1]Guangdong Provincial Institutional Drafting Committee Office Fundamental Reform of Party and Government Organizations in Shunde District of Foshan City, Guangdong Province Departmental System Reform Exploration and Practice, 2011 Edition.

[2]Guo Ming, Kong Wen. Decentralization and Empowerment: A Study of the Innovative Public Service Supply System in

Economically Developed Towns_A Case Study of the Reform of "Simplify Politics and Strengthen the town" in Shunde District. Theoretic Resources, 2017(01)

[3]Guangdong Provincial Party Committee Office, Provincial Government Office. Opinions of the General Office of the CPC Guangdong Provincial Committee and the General Office of the People's Government of Guangdong Province on Further Improving and Deepening the Administrative System Reform in Shunde, http://www.shunde.gov .cn/, 2017-3-23.

[4]General Office of the Guangdong Provincial Party Committee and the General Office of the People's Government of the

People's Republic of China. Opinions on Deepening the Reform of the Administrative System in Shenzhen, etc., http://www.yjbb.gov.cn/, 2017-3-23.

[5]Han Botian. Policy through Experiment: China's Unique Experience, Study of Contemporary Chinese History, May 2010.

[6]Xi Jinping. Completely building a well-to-do society to win a new era of socialism with Chinese characteristics, great victory, People's Publishing House, 2017 edition.

[7] Yu Keping. China's Local Government Innovation Case Study Report (2011-2012), Peking University Press, 2014. 